\title{
India's Growing Influence in the Gulf States: Political, Strategic and Economic Risks for Pakistan
}

\author{
Khurram Abbas*
}

\begin{abstract}
The paper explores India's growing role in the Gulf Cooperation Council (GCC), the primary drivers behind its success in fostering a strong economic and strategic relationship with Council members, and its implications for Pakistan. The study observes that Pakistan's policy of neutrality in Yemen's conflict, Saudi-Qatar impasse, and support of Iran's nuclear deal may have pushed the GCC states closer to India over the past few years. It also finds that unlike their economic relationship, security cooperation between India and the Gulf region is still limited in scope, but enhancing gradually. If India's political and security interaction further expands, it could deprive Pakistan of strong political and economic partners in the region which is New Delhi's ultimate strategic objective.
\end{abstract}

Keywords: Gulf States, Look West Policy, Indo-GCC Strategic Relationship, Geopolitics, Security, Trade.

* The author is Research Officer at the Islamabad Policy Research Institute. He is a PhD candidate at the Centre for International Peace \& Stability, National University of Sciences and Technology, Pakistan. He can be contacted at: khurram306pcips@nipcons.nust.edu.pk.

@ 2019 by the Islamabad Policy Research Institute.

IPRI Journal $\square$ XIX (2): 60-95.

https://doi.org/10.31945/iprij.190203. 
India's Growing Influence in the Gulf States: Political, Strategic and Economic Risks for Pakistan

\section{Introduction}

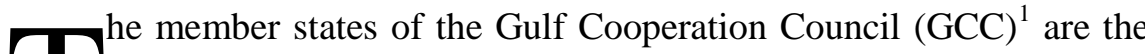
most important players in Middle East's politics. They are significant due to three major factors: natural resources, strategic location and political influence in the Muslim world. They possess more than 40 per cent of global crude oil reserves and 23 per cent of global natural gas reserves. ${ }^{2}$ Given technological advancements and research in the oil and gas sector, the world's dependence on this region for energy resources will further increase due to substantial industrial growth in Asian countries. The US Energy Information Administration predicts this dependence to increase up to 104 million b/d by $2020 .{ }^{3}$ The region is also an attractive destination for skilled and unskilled workers of South Asia. The remittances from the Gulf largely contribute to national economies of these countries.

Strategically, the GCC countries are located in one of the most active conflict zones in the world with simmering Arab and non-Arab rivalries, major powers' strategic competition, and the Israel-Palestine conflict. ${ }^{4}$ According to Stockholm International Peace Research Institute (SIPRI), military expenditures of these Gulf countries are significantly high in terms of their GDP. Saudi Arabia spends around 10.3 per cent of its total GDP on the military; Oman, Kuwait, UAE, Bahrain and Qatar, spend 12.1, 5.8, 5.6, 4.1, and 2 per cent, respectively. ${ }^{5}$ The largest

\footnotetext{
${ }^{1}$ This article refers to the six member countries of the Gulf Cooperation Council as the "Gulf States": Bahrain, Kuwait, Oman, Qatar, Saudi Arabia and the United Arab Emirates.

2 Economist, The GCC in 2020: Resources for the Future, report (Economist Intelligence Unit, 2010), http://graphics.eiu.com/upload/eb/GCC_in_2020_Resources_WEB.pdf.

3 "EIA Forecasts Relatively Flat Crude Oil Prices despite Lower Global Production Growth," US Energy Information Administration, March 13, 2019, https://www.eia.gov/petroleum/weekly/archive/2019/190313/includes/analysis_print.php.

${ }^{4}$ Riad Muhammad, "Geopolitics and Politics in the Arab Gulf States (GCC)," Geo Journal 13, no. 3 (1986): 201-210, doi: 10.1007/bf00704811; “Global Conflict Tracker," Council on Foreign Relations, March 6, 2019, https://www.cfr.org/interactive/global-conflict-tracker/?category=us.

5 "Data for All Countries from 1988-2018 as a Share of GDP," Stockholm International Peace Research Institute Military Expenditure Database, (2018): 14,
} 
percentage of arms imports is from the United States. Moreover, these countries are also vigorously spending on technology transfer, intelligence sharing with many European and Asian countries. ${ }^{6}$ Hence, they have significantly engaged many important countries through military cooperation and arms deals.

The GCC countries are not merely a source of energy resources; rather, they exercise strong influence in the entire Muslim world. This is evident from their role during the Cold War era. These six countries remained firm allies of the US, and galvanised the Muslim world to contain communism. ${ }^{7}$ This region is also the birthplace of the Salafi school of thought which has left a deep influence on various states and societies of the Muslim world.

\section{Brief Historical Overview of India's Foreign Policy towards the Gulf States}

The GCC states are not only important for the Muslim world, the US and European Union (EU), but also for Asian countries. India's relationship can be divided into four major phases. The first phase started 3,000 years ago when spice traders from the Indian subcontinent developed trade linkages with the Middle East and found a lucrative market. These economic linkages were further strengthened during the Muslim rule in India. ${ }^{8}$ The British ruled over the subcontinent after they overthrew the Mughal rulers in 1857; and reshaped its foreign policy according to their political objectives. During this era, security cooperation eclipsed the

https://www.sipri.org/sites/default/files/Data\%20for\%20all\%20countries $\% 20$ from $\% 201$ 988\%E2\%80\%932018\%20as\%20a\%20share\%20of\%20GDP\%20\%28pdf\%29.pdf.

${ }^{6}$ Gawdat Bhagat, "The Emerging Energy Landscape: Economic and Strategic Implications," in The Changing Security Dynamics of Persian Gulf, ed. Kristian Coates Ulrichsen (New York: Oxford University Press, 2018), 71, 73.

7 William Simpson, The Prince: The Secret Story of the World's Most Intriguing Royal, Prince Bandar Bin Sultan (New York: Harper Collins, 2008), 112.

${ }^{8}$ Chanda Nayan, "The Early Globalizers", India and Global Affairs Journal, OctoberDecember 2008, pp. 58-65; K.M. Panikar, India and the Indian Ocean: An Essay on the Influence of Sea Power on Indian History (London: George Allen \& Unwin, 1951), 2836; and Frederic Grare, India Turns East: International Engagement and US-China Rivalry (London: Hurst Publishers, 2016) 13. 
India's Growing Influence in the Gulf States: Political, Strategic and Economic Risks for Pakistan

historical economic bonds between the subcontinent and Gulf countries. On the other hand, Indian naval officers were deputed to the Suez Canal under the British Royal Navy in an attempt to control trade through the Mediterranean, Red and Arabian Sea. The third phase spans 1947 to 1990 during which India's nonalignment policy and inward looking economic approach did not allow its policy-makers to focus their efforts on deeper cooperation. ${ }^{9}$ However, even during this time, it signed various bilateral trade and energy security agreements. Likewise, many bilateral state visits took place between Saudi Arabia and India in $1956^{10}$ and 1981 which led to the establishment of the Joint Commission on Economic, Trade, Science, Technical and Cultural Cooperation. ${ }^{11}$ The UAE also remained engaged through bilateral state visits in 1975, 1976, 1981 and $1982 .{ }^{12}$ Qatar, Oman and Kuwait also had ministerial level bilateral visits in the 1970s and 1980s.

The fourth phase started after the Cold War, when Iraq invaded Kuwait in 1991. This war proved to be a turning point in restructuring India's foreign policy approach towards the region because it severely impacted the country's economy and stranded Indian workers in both wartorn countries. ${ }^{13}$ Subsequently, India tried to secure its oil supplies through various agreements such as the Delhi Declaration. ${ }^{14}$ Compared to pre-

${ }^{9}$ Grare, India Turns East, 14, 15.

${ }^{10}$ Shamsur Rabb Khan, "Need a Strategic Partnership with Saudi Arabia," Institute of Peace and Conflict Studies, May 6, 2008,

www.ipcs.org/article_details.php?articleNo=2560; Geoffrey Kemp, The East Moves West: India, China and Asia's Growing Presence in the Middle East (Washington, D.C.: Brookings Institution Press, 2010), 37.

11 "Indo-Saudi Economic and Commercial Relations," Consulate General of India, www.cgijeddah.com/cgijed/COMM/bilateral/ISBER.htm; and, Kemp, The East Moves West, 38.

12 Indian Embassy, Abu Dhabi, "India- UAE Bilateral Relations," accessed August 23, 2018, www.indembassyuae.org/induae_bilateral.phtml; Ibid., 47.

${ }^{13}$ The impact of this war has been discussed later to understand India's changing behaviour towards the region.

${ }^{14}$ This declaration was signed by King Abdullah bin Abdul Aziz Al Saud and Prime Minister Manmohan Singh on January 27, 2006. The agreement is considered historic. It was agreed that both countries would closely and actively cooperate to fight terrorism and other transnational crimes like money laundering, drugs and arms smuggling in a 
1991 when it had an overwhelming reliance on Iraq and Kuwait for oil and gas supplies, India shifted its dependence on Saudi Arabia, UAE and Qatar. ${ }^{15}$ Moreover, the 1990 s witnessed enhanced cooperation in matters such as terrorism and joint military exercises. In this regard, Oman was the first country that signed a Memorandum of Understanding (MoU) in 1996 with India to combat terrorism and piracy. Moreover, navies of the two countries began cooperation on joint defence in $1998 .{ }^{16}$ This expanded cooperation later culminated in a well-thought political strategy — India's 'Look West Policy.'

\section{India's Look West Policy}

This policy was formally announced by then-Prime Minister Manmohan Singh on July 27, 2005 and sought strong ties with neighbours to the country's west ranging from Afghanistan to the Persian Gulf. However, its primary focus remains the Gulf region. Frequent bilateral visits, defence and security cooperation, security of oil and gas supplies, and welfare of Indian workers are the main determinants of this comprehensive policy, apart from cooperation in technology transfer, anti-piracy, etc. After its announcement, a series of state-level visits took place between the Arab countries and India. Former Prime Minister Manmohan Singh visited Oman and Qatar in November 2008. During this visit, he signed various agreements related to security, defence, and energy. ${ }^{17}$ India and Oman had agreed to establish a joint investment fund of USD 300 million in 2008 expected to expand to USD 1.5 billion. ${ }^{18}$ Likewise, both countries decided to expand cooperation in tourism, infrastructure development and health. In April 2009, Vice President of India Hamid Ansari visited

sustained and comprehensive manner. The two also agreed to expand and diversify

mutual trade and investments under the agreement.

${ }^{15}$ Kemp, The East Moves West: India, China and Asia's Growing Presence in the Middle East, 27.

${ }^{16}$ Ibid., 43.

${ }^{17}$ Prasanta Kumar Pradhan, Accelerating India's Look West Policy in the Gulf, report (New Delhi: Institute of Defense Studies and Analyses, February 3, 2011), https://idsa.in/system/files/IB_IndiaLookWestPolicy.pdf, 2.

18 “Oman-India Joint Investment Fund," accessed August 25, 2018, http://www.oijif.com/about-us/. 
India's Growing Influence in the Gulf States: Political, Strategic and Economic Risks for Pakistan

Kuwait and signed three important agreements including the Education Exchange Programme, Cooperation in Science and Technology, and Cultural Exchange Programme. ${ }^{19}$ On February 27, 2010, Manmohan Singh visited Saudi Arabia and signed the Riyadh Declaration. This declaration was the first document between the two that condemned terrorism and extremism. They also agreed to exchange information related to terrorist activities, money laundering, human trafficking, information and space technology and education. This was the start of a new strategic partnership between the two. ${ }^{20}$

The current Prime Minister, Narendra Modi has given impetus to this policy and has personally enhanced outreach to Arab rulers. The 2014 Defence and Cooperation agreement between Saudi Arabia and India was a milestone in bilateral cooperation. ${ }^{21}$ Modi has visited UAE twice (August 2015 and February 2018) and signed the Dubai Declaration in 2015. According to this Declaration, both countries share common challenges, including drug trafficking, money laundering, security and stability of the Gulf region. It also indicates that both countries have a common understanding about cross-border terrorism. ${ }^{22}$ Though, India has not been able to sign Free Trade Agreements (FTAs) with any GCC member state, yet the 'Look West' policy has provided dividends in security and economic spheres. This extensive outreach has also convinced many Arab countries that India is an important international partner and a significant regional player in Asia, which has greatly helped the latter to consolidate its position within the region.

\footnotetext{
${ }^{19}$ Pradhan, Accelerating India's Look West Policy, 3.

${ }^{20}$ Hussain, Saudi Arabia in a Multipolar World, 167.

${ }^{21}$ Ankit Panda, "India and Saudi Arabia Sign Defense Cooperation Pact," Diplomat, February 27, 2014, https://thediplomat.com/2014/02/india-and-saudi-arabia-signdefense-cooperation-pact/.

${ }^{22}$ Sanjaya Baru, "The Sprouting of the 'Look West' Policy," Hindu, August 19, 2015, https://www.thehindu.com/opinion/lead/sanjaya-baru-writes-the-sprouting-of-the-lookwest-policy/article7554403.ece.
} 
Khurram Abbas

\section{Primary Drivers of Indo-GCC Cooperation}

\section{Economic Drivers}

\section{Trade}

India considers the Gulf region as its 'economic neighbourhood'. In March 2006, India's Minister for Commerce and Industry Kamal Nath stated:

India and the member states of the Gulf Cooperation Council (GCC) have historic ties that go back not merely decades, but centuries. It is significant that the earliest contacts between the Gulf States and India were based on trade, with dhows and ships crossing the Arabian Sea. Indeed the Gulf region is part and parcel of India's economic neighbourhood. ${ }^{23}$

India and the GCC states have strong economic ties which increased to USD 84.96 billion in 2017-18, from USD 7.8 billion in 2003-04. Currently, the Gulf region accounts for 12.98 per cent of India's total exports, while it has 13.76 per cent share of its total imports. UAE and Saudi Arabia are the largest shareholders of total imports from the Gulf region $^{24}$ (see Table 1):

${ }^{23}$ Kemp, The East Moves West: India, China and Asia's Growing Presence in the Middle East, 25.

${ }^{24}$ GoI, "Region-wise Exports, Export Import Databank," (Ministry of Commerce and Industry, Government of India, 2004), http://commerce-app.gov.in/eidb/irgncntq.asp; and, GoI, "Export Import Databank," (Ministry of Commerce and Industry, Government of India, 2018), http://commerce-app.gov.in/eidb/irgncntq.asp. 
India's Growing Influence in the Gulf States: Political, Strategic and Economic Risks for Pakistan

Table-1

India's Imports from the Gulf States (Value: USD million)

\begin{tabular}{lccc}
\hline \multicolumn{1}{c}{ Country } & $\mathbf{2 0 0 6 - 0 7}$ & $\mathbf{2 0 1 2 - 1 3}$ & $\mathbf{2 0 1 7 - 1 8}$ \\
\hline Bahrain & 471.23 & 664.66 & 431.12 \\
Kuwait & 5993.23 & 16588.13 & 7165.70 \\
Oman & 458.90 & 2009.72 & 4264.29 \\
Qatar & 2060.08 & 15693.08 & 8409.08 \\
Saudi Arabia & 13355.33 & 33998.11 & 22069.96 \\
United Arab Emirates & 8655.28 & 39138.36 & 21739.96 \\
\hline
\end{tabular}

Source: GoI, "Region-wise Imports, Export Import Databank," (Ministry of Commerce and Industry, Government of India, 2018), accessed August 05, 2018, http://commerce-app.gov.in/eidb/irgnentq.asp.

Table-2

India's Exports from Gulf States (Value: USD million)

\begin{tabular}{lccc}
\hline \multicolumn{1}{c}{ Country } & $\mathbf{2 0 0 6 - 0 7}$ & $\mathbf{2 0 1 2 - 1 3}$ & $\mathbf{2 0 1 7 - 1 8}$ \\
\hline Bahrain & 184.52 & 603.47 & 556.82 \\
Kuwait & 614.81 & 1061.08 & 1497.99 \\
Oman & 630.97 & 2599.49 & 2728.30 \\
Qatar & 331.53 & 687.18 & 1471.88 \\
Saudi Arabia & $2,590.77$ & 9785.70 & 5410.70 \\
United Arab Emirates & $12,021.77$ & 36316.65 & 31175.50 \\
\hline
\end{tabular}

Source: GoI, "Export Import Databank," (Ministry of Commerce and Industry, Government of India, 2018), http://commerceapp.gov.in/eidb/irgnentq.asp. 


\section{Khurram Abbas}

Table 1 shows that Saudi Arabia and UAE have emerged as dominant trading partners of India over the past decade, with exports and imports increasing substantially. Apart from Bahrain, which has remained embroiled in a serious internal conflict; other countries of the GCC have expanded their trade with India. Trade was mainly restricted to oil, spices and labour until $2000,{ }^{25}$ however, in the past 19 years, its scope has expanded to fertilizers, petrochemicals, services, IT, gold, and textiles. India and the GCC states are signatories of the Framework Agreement of Economic Cooperation (FAEC) which was signed in New Delhi on August 25, 2004. Under this agreement, they are working closely to establish a conducive environment for business and trade. In this regard, India-GCC industrial forum was established in February 2004, which enhanced trade and technology transfer activities. ${ }^{26}$ Moreover, India granted Most Favoured Nation (MFN) status to the GCC states with the hope that it would help to secure a FTA. ${ }^{27}$ Gulf countries have been reluctant to enter into FTAs with Asian countries in general and with India, Pakistan and China in particular because it would severely damage their competitiveness. ${ }^{28}$ Gulf countries are establishing new industries which require time to become competitive.

Many large industrial groups such as Taizoon Khorakiwala, Khimji Group, the Jashanmals, Mann Chabria, TATA Group, Aditya Birla Group, have been investing in the region. ${ }^{29}$ They have been heavily investing in real estate, retail stores, hotels, restaurants, textiles, and gold. According to the Dubai Chambers of Commerce (DCC), Indian companies are eager

${ }^{25}$ Girijesh Pant, "The Changing Gulf Market and India: Trends and Prospects" in Perspectives on India and Gulf States, ed. A.K Pasha (New Delhi: Détente Publishers, 1999), 112-126.

${ }^{26}$ Samir Pradhan, "India and the Gulf Cooperation Council (GCC): An Economic and Political Perspective," Strategic Analysis 34, no.1 (2010): 93-103, https://doi.org/10.1080/09700160903351340.

${ }^{27}$ Zahid Shahab Ahmed and Stuti Bhatnagar, "Gulf States and the Conflict between India and Pakistan," Journal of Asia Pacific Studies 1, no.2 (2012):259-291, https://www.humanitarianlibrary.org/sites/default/files/2014/02/8.\%20Zahid.pdf.

${ }^{28}$ Asad Zaman (then-Vice Chancellor, Pakistan Institute of Development Economics), in discussion with the author, March 8, 2019.

${ }^{29}$ Qasim Minhas, Adeel Hussain, Wahab Ahmed and Arif Hussain (Pakistani workers in Saudi Arabia and UAE), in discussion with the author, August 14, 2018. 
India's Growing Influence in the Gulf States: Political, Strategic and Economic Risks for Pakistan

to invest in Dubai. In 2008, 12,359 Indian companies were registered with the Chamber. This figure tripled in a decade. Currently, 38,238 Indian companies are registered, while DCC has opened its international office in India to facilitate the business community. ${ }^{30}$

According to the Saudi Arabia General Investment Authority (SAGIA), there were 426 Indian companies registered for business in Saudi Arabia by 2017, compared to 190 in 2007, which shows a 150 per cent growth. ${ }^{31}$ Moreover, hundreds of Indian companies are registered as well as actively engaged in business activities in UAE Free Economic Zones. For instance, more than 700 Indian companies are registered with the JLT Free Zone. Similarly, Jabel Ali Free Zone, Ras Al Khaimah (RAK), Fujairah Free Trade Zone, Hamriyah Free Trade Zone, Sharjah Airport International Free Zone and Ajman Free Zone have hundreds of registered companies making India one of the largest trading partners of UAE. $^{32}$

This economic engagement is not confined to the private sector; rather, Indian Public Sector Enterprises (PSEs) are also working in the Gulf region. Tea Board of India, Bharat Heavy Electricals Ltd, Indian Airlines, State Bank of India, National Thermal Power Corporation, etc., along with numerous educational institutions are providing their services in the region. The Saudi Arabia's Knowledge Economic City at Medina is hosting numerous Indian IT firms. ${ }^{33}$ This extensive economic engagement and interdependence has been cordially reciprocated with political warmth for India and its business community by the Gulf countries, which has further provided a favourable environment for Indian business and trade.

\footnotetext{
${ }^{30}$ Dubai Chamber of Commerce and Industry, "Dubai Chamber Strengthens Global Presence with Opening of India Office," accessed August 9, 2018, http://www.dubaichamber.com/whats-happening/chamber_news/dubai-chamberstrengthens-global-presence-with-opening-of-india-office.

${ }^{31}$ Embassy of India, Kingdom of Saudi Arabia, "India-Saudi Arabia Bilateral Relations," accessed August 10, 2018, http://www.indianembassy.org.sa/india-saudi-arabia/indiasaudi-bilateral-relations.

32 Babu Das Augustine, "India to Become UAE's Largest Trade Partner in 2030," Gulf News, December 15, 2016, https://gulfnews.com/business/sectors/tourism/india-tobecome-the-uae-s-largest-trade-partner-by-2030-1.1947103.

${ }^{33}$ Pradhan, India and the Gulf Cooperation Council, 93-103, 40.
} 


\section{Khurram Abbas}

During the visit of Crown Prince Muhammad bin Salman, agreements related to infrastructure development, tourism, and construction of houses in India were signed. ${ }^{34}$ Trade and investment are vital factors in the evolving Indo-GCC relationship.

\section{Energy Security}

In 2014-15, India imported 109.88 million tonnes of oil from the world, out of which 58 per cent came from the Gulf region. Due to its rapid economic growth and massive population, it is among the top four oil consuming countries of the world - others being the US, China and Japan. ${ }^{35}$ Saudi Arabia, Kuwait and UAE are supplying 26,882 tonnes, 14,611 tonnes, and 10,433 tonnes oil to India, respectively. ${ }^{36}$ Qatar and Oman are its largest natural gas suppliers. Qatar is supplying 8.25 billion cubic meters natural gas, while Oman and UAE are exporting 0.35 billion cubic meters and 0.17 billion cubic meters, respectively. ${ }^{37}$ India is also establishing a Strategic Petroleum Reserve in Padur, Karnataka with the help of $\mathrm{UAE}^{38}$ which has further increased its dependency on the region. Furthermore, Indian Oil and Gas Corporation is working along with Saudi Arabia for the establishment of a refinery in Andhra Pradesh. ${ }^{39}$ The

\footnotetext{
${ }^{34}$ Ministry of External Affairs India, "List of MoUs/Agreements Signed during State Visit of Crown Prince of Saudi Arabia to India," February 20, 2019 , https://www.mea.gov.in/bilateral-

documents.htm?dt1/31070/List_of_MoUsAgreements_signed_during_State_Visit_of_Cr own_Prince_of_Saudi_Arabia_to_India; Zeenat Saberin, "India, Saudi Arabia Sign Investment Agreements as MBS Meets Modi," Al Jazeera, February 20, 2019, https://www.aljazeera.com/news/2019/02/india-saudi-arabia-sign-investment-deals-mbsmeets-modi-190220103010939.html.

35 "India's Oil Imports from Middle East rises to 59\%," Economic Times, April 25, 2016, https://economictimes.indiatimes.com/news/economy/foreign-trade/indias-oil-importfrom-middle-east-rises-to-59/articleshow/51979614.cms.

${ }^{36}$ GoI, "Export Import Databank."

37 BP Statistical Review of World Energy, BP Statistical Review of World Energy June 2010, report (London: BP p.l.c, June 2010), www.bp.com/statisticalreview.

38 "India-UAE Strategic Oil Reserves Deal: 10 Things to Know," Times of India, January 26, 2017. https://timesofindia.indiatimes.com/business/india-business/india-uaestrategic-oil-reserves-deal-10-things-to-know/listshow/56793334.cms.

${ }^{39}$ Harsh V. Pant, "India's Relations with Iran: Much Ado about Nothing," Washington Quarterly 34, no. 1 (2011):61-74, https://doi.org/10.1080/0163660X.2011.534964.
} 
India's Growing Influence in the Gulf States: Political, Strategic and Economic Risks for Pakistan

project has been stalled due to land acquisition issues. ${ }^{40}$ Currently, India has 5.33 million tonnes of oil reserves, enough for nine days during any crisis. ${ }^{41}$ New Delhi's eagerness to expand this capacity will most likely help this project to be completed timely.

India's concerns regarding its energy security could be traced back to the First Gulf War between Iraq and Kuwait in August 1990, which proved to be a bitter experience for the country. Before August 1991, it was overwhelmingly dependent on Iraq and Kuwait for oil imports. At that time, it was importing 40 per cent of its total oil from these two countries, and Iraq's invasion severely restricted oil supplies. ${ }^{42}$ This war led to structural reforms in the country's energy policy. This was also the time when India introduced the policy of trade liberalisation and gave prominence to the Gulf region for oil imports. ${ }^{43}$ This also means that peace along the oil routes is in the vital interest of India. Therefore, it is not only extensively working to build legal frameworks for energy trade with the Gulf region, it is also enhancing its strategic presence. India put a clause of stability of oil trade with Saudi Arabia in the Delhi Declaration. ${ }^{44}$ Moreover, India has signed security pacts with Bahrain, Oman, Saudi Arabia, UAE and Qatar to deal with any possible terror attack against its lines of oil supply routes. ${ }^{45}$ Hence, India's fear of energy security is providing stimulus for security cooperation with the Arab States.

\footnotetext{
${ }^{40}$ Saberin, "India, Saudi Arabia Sign Investment Agreements as MBS Meets Modi."

41 "Initial Pact with UAE Company for Strategic Oil Reserve at Padur," Economic Times, November 13, 2018,

//economictimes.indiatimes.com/articleshow/66584667.cms?utm_source=contentofinter est\&utm_medium=text\&utm_campaign=cppst.

${ }^{42}$ Kemp, The East Moves West: India, China and Asia's Growing Presence in the Middle East, 27.

${ }^{43}$ Pradhan, "India and the Gulf Cooperation Council (GCC)."

${ }^{44}$ Kemp, The East Moves West: India, China and Asia's Growing Presence in the Middle East, 38.

45 Ibid., 68.
} 
Khurram Abbas

\section{Political Drivers}

\section{The China Factor}

One of India's major foreign policies in the post-Cold War era has been to counter a rising China. Both are attempting to create their respective spheres of influence. India considers growing Chinese influence in the Gulf region a challenge to its economic and strategic interests since they can 'swallow each other's economic share in the region. ${ }^{46}$

According to the Chinese Ministry of Commerce, trade between China and GCC countries exceeded USD 171 billion in 2017. ${ }^{47}$ Moreover, China is also aggressively pursuing the Gulf region for signing FTAs. In this regard, nine rounds of talks have been completed. ${ }^{48}$ If China secures FTA from the GCC, it is more likely that Indian economic interests will be negatively affected since each is competing for cheaper oil agreements and export of non-oil goods such as labour-intensive goods like textile, iron, steel, rice, wheat, kitchen items, household articles, and electronics. ${ }^{49}$ India is currently lagging behind China in non-oil goods exports. However, it is striving to reduce this gap by developing various bilateral forums for strategic cooperation. In this regard, the GCC-China Business Forum and GCC-China Strategic Dialogue are strategic forums for institutionalisation of bilateral trade and investment. ${ }^{50}$ Furthermore,

\footnotetext{
${ }^{46} \mathrm{Dr} \mathrm{Hu}$ Shisheng (Director South and East Asia, Chinese Institutes of Contemporary International Relations) in discussion with the author, August 28, 2018.

${ }^{47}$ Ministry of Commerce, People's Republic of China, Achievements of Economic and Trade Cooperation between China and West Asia and Africa since the Holding of the Eighteenth National Congress of the Communist Party of China, October 18, 2017.

${ }^{48}$ Ministry of Commerce, People's Republic of China, "The $9^{\text {th }}$ Round of China-GCC FTA Negotiations Concluded," accessed August 3, 2018, http://english.mofcom.gov.cn/article/newsrelease/significantnews/201612/20161202372 433.shtml.

${ }^{49}$ Dr Hu Shisheng (Director South and East Asia, Chinese Institutes of Contemporary International Relations) in discussion with the author, August 28, 2018.

${ }^{50}$ Pradhan, Accelerating India's Look West Policy in the Gulf, 45-57.
} 
India's Growing Influence in the Gulf States: Political, Strategic and Economic Risks for Pakistan

Beijing has also been promoting cooperation with Arab states under President Xi's Belt and Road Initiative (BRI) ${ }^{51}$

Indian strategists also consider China a challenge to their energy and maritime security. This is apparent from the Indian Maritime Doctrine of 2004 and India's Maritime Strategy of 2015, which point to Beijing as a major security threat to its maritime security. Overall, India wants to secure four major entry points - Strait of Hormuz, Suez Canal, Strait of Bab-el-Mandab and Cape of Good Hope.$^{52}$ It fears that China may use its growing influence to overcome the 'Malacca Dilemma' ${ }^{53}$ Therefore, the Indian Navy has been extensively engaged with naval forces of Arab countries through regular exercises in order to ensure its active presence in the region. Hence, China has emerged as another motivating factor behind India's evolving relationship with the Gulf.

\section{The US Factor}

India had been increasingly developing its strategic relationship with Iran until the US-Iran rivalry changed the course of its foreign policy. The US factor has played a significant role in shaping India's attitude towards the Gulf region. In February 2006, India voted against Iran's nuclear programme. The Bush administration had warned that if India did not vote against Iran, it would revisit its decision on the future of a civil nuclear deal. ${ }^{54}$ Later, a clause was added in the Indo-US Civil Nuclear pact as 'statement of policy' that India would support the US to contain Iran from acquisition of nuclear weapons through all means, including imposition of

\footnotetext{
${ }^{51}$ Xuming Qian, "The Belt and Road Initiatives and China-GCC Relations," International Relations and Diplomacy 5, no.1 (2017): 687-693, doi: 10.17265/23282134/2017.11.005.

52 Indian Navy, Indian Maritime Security Doctrine 2015, accessed August 15, 2018 , https://www.indiannavy.nic.in/content/indian-maritime-doctrine-2015-version.

${ }^{53}$ The Malacca Dilemma is a term coined by President Hu Jintao in 2003 on the overreliance of Chinese oil imports from the Malacca Straits where 80 per cent of their energy needs (oil imports) en-route from the Middle East, Angola etc. China has repeatedly showed its concerns that this entry point can be chocked during any conflict with India or the US.

${ }^{54}$ R. Ramachandran, "Iran Policy was Key to Nuclear Deal with US," Hindu, September 30, 2005.
} 
economic sanctions. ${ }^{55}$ This was implicit encouragement from the US to enhance cooperation with other powers in the region such as Saudi Arabia.

Pant believes that such anti-Iran policies of the US have largely shaped Indian priorities in the region. ${ }^{56}$ Therefore, India has decided to actively engage with friendly countries of the US in the region such as Saudi Arabia, UAE and Israel. While it has taken its own stance on Yemen's war, Qatar's diplomatic crisis and the Syrian war; yet, its stance on Iran's nuclear programme was synchronised with Saudi Arabia and GCC's interests. It seems that the economic sanctions on Iran have helped deepen Indo-Saudi ties. India was the second largest oil buyer from Iran, however, amid international sanctions, it became the sixth largest oil buyer by $2016 .{ }^{57}$ The US' exit from the Joint Comprehensive Plan of Action (JCPOA) will further strengthen Indo-Saudi relations.

Similarly, the US has offered India a larger role in the 'Greater South Asian' security architecture. ${ }^{58}$ Trump's 'South Asia Policy' and the Indo-US strategic partnership provide India a favourable environment to deepen cooperation with key countries of the Middle East, Asia-Pacific and Africa. ${ }^{59}$ The main purpose of the US strategy is to enhance India's stature as a balancer to rising China. Similarly, the US has renamed its

\footnotetext{
${ }^{55}$ United States Congress, "H.R. $5682\left(109^{\text {th }}\right)$ : Henry J. Hyde United States and India Nuclear Cooperation Promotion Act of 2006," Govtrack.us, accessed August 11, 2018, http://www.govtrack.us/congress/billtext.xpd?bill=h109-5682.

${ }^{56}$ Pant, "India's Relations with Iran."

${ }^{57}$ Zoe Leung and Hari Prasad, "Why Continued Indian Engagement with Iran is in America's Interest,” Diplomat, October 23, 2018, https://thediplomat.com/2018/10/whycontinued-indian-engagement-with-iran-is-in-americas-interest/; and, "Iraq Replaces Saudi Arabia as India's Lead Oil Supplier,” Economic Times, December 18, 2017, https://economictimes.indiatimes.com/news/economy/foreign-trade/iraq-replaces-saudiarabia-as-indias-lead-oil-supplier/articleshow/62120071.cms.

${ }^{58}$ Senator Mushahid Hussain, Chairman Defence Committee of the Senate of Pakistan coined this term during his visit to Washington in 2016. The Greater South Asian region refers to an economic alliance which would include China, Iran and the Central Asian Republics in addition to the South Asian countries. "What's Greater South Asia?," Indian Express, October 13, 2016, http://www.newindianexpress.com/opinions/editorials/2016/oct/13/whats-a-greatersouth-asia-1527320.html.

${ }^{59}$ Col. (R) Muhammad Hanif (Senior Defence Analyst), in discussion with the author, December 28, 2018.
} 
India's Growing Influence in the Gulf States: Political, Strategic and Economic Risks for Pakistan

Asia-Pacific Command as the Indo-Pacific Command. ${ }^{60}$ The US academia largely shares the idea that Indian role in comparison to China in the 'Indo-Pacific' would guarantee a more stable balance of power. ${ }^{61}$

This has apparently enhanced the political clout of New Delhi in the region and beyond. Apart from its geography, market size and abundant workforce, India has emerged as an important player in South Asia and beyond due to overt US support. Hence, it is safe to claim that Washington has been facilitating Indo-GCC growing cooperation in order to undermine Iranian and Chinese interests in the region.

\section{Security Cooperation}

India has bilateral defence cooperation with Saudi Arabia, UAE, Oman and Qatar for military training, intelligence sharing, combating terrorism and money laundering. Among all GCC states, Oman holds special attention as it signed a military protocol in 1972; formed a Joint Military Cooperation Committee in 2008; held Air Force-to-Air Force staff talks in 2009; and inked the MoU on military cooperation which provides the Indian Navy access to the Duqm Port in $2018 .^{62}$

India and the UAE signed the Strategic Dialogue in 2003 which allows import and export of arms. ${ }^{63}$ Both also regularly hold meetings under the India-UAE Defence Cooperation Committee which was established in 2003. UAE has also extradited a number of terrorists to India. ${ }^{64}$

\footnotetext{
60 "US Pacific Command Renamed as US Indo-Pacific Command," Economic Times, June 2, 2018, https://economictimes.indiatimes.com/news/defence/us-pacific-commandrenamed-as-us-indo-pacific-command/articleshow/64398189.cms.

${ }^{61}$ Chris Coons and Puneet Talwar, "The Case for a US-India Partnership," National Interest, October 20, 2018, https://nationalinterest.org/feature/case-us-india-partnership33862 .

${ }^{62}$ Ibid., 44-46.

63 Kemp, The East Moves West: India, China and Asia's Growing Presence in the Middle East, 58.

64 Ibid., 58.
} 
India and Saudi Arabia also have an extradition treaty signed in March 2010 ${ }^{65}$ It was due to this treaty that Saudi Arabia handed over Abu Jandal $^{66}$ to India in $2012 .{ }^{67}$ However, while India has not been able to secure any sufficient arms deal with the GCC states given their dependence on the US and EU (as indicated earlier), such deals in the future cannot be ruled out.

\section{Cultural Drivers}

\section{Diaspora in the Gulf}

India surpassed China in remittance inflows with USD 69 billion in $2017 .{ }^{68} 55$ per cent of the total remittance inflow to the former is from the Middle East. According to an estimate, one Gulf worker can financially support around 20 family members in India. ${ }^{69}$ As of December 2017, more than 8.7 million Indians were living and working in the Gulf region in different capacities. Saudi Arabia and UAE are hosting the largest number, i.e., 3.2 million and 2.8 million Indians, respectively. Moreover, Bahrain, Kuwait, Oman and Qatar are hosting 0.31 million, 0.91 million, 0.78 million, and 0.69 million Indians, respectively. The southern states of India such as Kerala, Tamil Nadu and Andhra Pradesh are contributing the

65 “India, Saudi Arabia Sign Extradition Treaty," Hindu, March 1, 2010, https://www.thehindu.com/news/India-Saudi-Arabia-sign-extraditiontreaty/article16462354.ece.

${ }^{66} \mathrm{He}$ is accused of being involved in the Mumbai attacks November 26, 2008. He is a suspect in several cases such as the Kalupur Station blast case of February 2006 and the Aurangabad Arms Haul case of May 2006.He is also a co-accused in the 2010 Pune bombing case. On August 2, 2016, he was sentenced to life imprisonment for the arms haul.

67 "Why the Saudis Deported Abu Jundal," Indian Express, July 13, 2012, https://indianexpress.com/opinions/columns.

${ }^{68}$ The World Bank, "Record High Remittances to Low- and Middle-Income Countries in 2017,” April 23, 2018, http://www.worldbank.org/en/news/pressrelease/2018/04/23/record-high-remittances-to-low-and-middle-income-countries-in2017.

${ }^{69}$ Shafeeq Rahman, "Why Remittances from the Middle East Matter to India," Fair Observer, February 26, 2018,

https://www.fairobserver.com/region/middle_east_north_africa/global-remittancesmiddle-east-gulf-india-labor-force-news-43199/. 
India's Growing Influence in the Gulf States: Political, Strategic and Economic Risks for Pakistan

largest share to the expatriate community, many of whom are white collar professionals as well as blue collar workers. ${ }^{70}$ Indian professionals have become a necessity for many Gulf countries due to their overwhelming presence in every sphere of life. There is hardly any company in the Gulf that has no Indian employee. In 2007, then-UAE's Minister for Labour, Ali Bin Abdullah al Kaabi stated:

God forbid something happens between us and India and they say 'please we want all our Indians', our airports would shut down, our streets and construction sites would be empty. ${ }^{71}$

The security and well-being of Indian expatriates as well as hope for increased remittances are two prominent reasons for India's growing cooperation with the Gulf States. It is eagerly trying to secure legal rights for Indian workers and has signed various protocols and agreements with hosting nations for protection and better treatment of its citizens. In November 2007, India signed a protocol with Qatar for the welfare of the Indians. This protocol ensures elimination of illegal practices and mistreatment against Indian workers by the Qatari citizens. The first Gulf war severely dented India's interests, as almost 150,000 Indian workers were stranded, while the Indian government spent enormous resources not only on their safe evacuation, but also for their repatriation and resettlement in the country. ${ }^{72}$ India does not want to repeat such episodes as it would be detrimental for its economy. Therefore, it is developing close cooperation with the hosting Gulf countries for the security and well-being of its Diaspora.

\footnotetext{
${ }^{70}$ Ministry of External Affairs, Government of India, "Population of Overseas Indians," accessed August 9, 2018, http://mea.gov.in/images/attach/NRIs-and-PIOs_1.pdf.

${ }^{71}$ Jason De Parle, "Fearful of Restive Foreign Labor, Dubai Eyes Reforms," New York Times, August 6, 2007, www.nytimes.com/2007/08/06/world/middleeast/06dubai.html.

72 "Qatar Gives Indians Wage Pact to Smile," Peninsula, November 21, 2007, www.zawya.com/Story.cfm/sidZAWYA20071123083121/SecMain/pagHomepage/chn All\%20Regional\%20News/obj2A17E941-F5E0-11D4-867D00D0B74A0D7C/.
} 
Khurram Abbas

India's Soft Image in the Gulf

India's overall positive image has also contributed in its better relationship with the Gulf. One of the important reasons for high acceptability ratio of its workers is the country's soft image in general, and 'obedient' behaviour of Indian expatriate community, in particular. According to Pakistani workers, the 'obedient' behaviour and good moral character of Indian workers encourages their employers to import more. This expatriate community has been considered one of the important soft power assets for India. This image has also been strengthened due to India's cultural diplomacy. In this regard, its film industry has played a significant role. For instance, in October 2007 Abu Dhabi organised an International Film Festival where Bollywood dominated the show. The Bollywood stars experienced preferential treatment by the organisers. ${ }^{73}$ Likewise, Modi's government started 'Project Mausam' to highlight the country's historic maritime trade and civilisational links with the Gulf countries. ${ }^{74}$ Through this project, Indian Ministry of Culture is organising cultural events in the GCC states on a regular basis. It is because of such cultural initiatives and positive image that UAE allowed establishment of a Hindu temple in Abu Dhabi. ${ }^{75}$ Likewise, despite being a non-Arab state India enjoys its observer status in the Arab League (AL). Recently, India was invited by the Foreign Minister of UAE Sheikh Abdullah bin Zayed Al Nahyan to attend the meeting of the Organization of Islamic Cooperation (OIC) as a 'guest of honor' ${ }^{76}$ This development illustrates the 'good will' that India has been enjoying with the GCC. These developments indicate that India enjoys positive image, which helps it to

\footnotetext{
${ }^{73}$ Qasim Minhas et al., in discussion with the author, August 14, 2018.

${ }^{74}$ Alysssa Ayres, Our Time Has Come: How India is Making its Place in the World (New York: Oxford University Press, 2018), 107.

${ }^{75}$ Anjana Sankar and Ashwani Kumar, "First Hindu Temple in Abu Dhabi to be Completed by 2020," Khaleej Times, February 11, 2018, https://www.khaleejtimes.com/uae-india-ties//First-Abu-Dhabi-Hindu-temple-to-comeup-on-55,000-square-metres-of-land-

76 "In a $1^{\text {st }}$, India Invited to OIC Meet as 'Guest of Honour," Times of India, February 24, 2019,http://timesofindia.indiatimes.com/articleshow/68132243.cms?utm_source=conten tofinterest\&utm_medium=text\&utm_campaign=cppst.
} 
India's Growing Influence in the Gulf States: Political, Strategic and Economic Risks for Pakistan

not only secure but further expand its economic and political interests in the region.

\section{Implications for Pakistan}

Since Pakistan's inception in August 1947, the country has strived to develop close and brotherly ties with the GCC states as a major pillar of its foreign policy driven by religious bonds, economic interests and political relationships on issues affecting the Muslim world in general. Pakistan has not only helped them in institution-building during their formative years, it has also provided support during times of crisis. In return, Arab countries have favoured Pakistan politically, diplomatically and economically, especially during the period of economic sanctions. ${ }^{77}$ There is a long list of bilateral agreements between Pakistan and the GCC states. However, given India's growing footprint, this subsequent section will try to explore whether this poses any potential risk to Pakistan's political, strategic and economic interests in the region.

\section{Political Risks}

The Gulf region has been going through massive strategic realignments in the aftermath of Arab Spring in 2011. The fall of dictatorial regimes, war in Yemen, rise and fall of the Islamic State of Iraq and Syria (ISIS), intraArab conflicts such as Qatar diplomatic crisis, Iran's nuclear deal and subsequent US exit, etc., have shaped the strategic thinking of the Arab ruling elite. This has also intensified competition between two blocs of the region - Saudi Arabia and the US against Russia, Iran and Syria. ${ }^{78}$ Furthermore, the sharp fall in global oil prices since 2014 has intensified debate among the Arab elite regarding the need to rethink socioeconomic

\footnotetext{
${ }^{77}$ Air Cdr. (R) Khalid Iqbal, (Senior Defence Analyst and Chairman, Institute of Policy Studies Committee on Pakistan's Geostrategic and Geopolitical Dynamics) in discussion with the author, September 8, 2018.

${ }^{78}$ Imtiaz Gul, "Pakistan's Relations with US," (speech, Media Workshop, Pakistan's Relations with US, China and Russia, Islamabad Policy Research Institute, August 29, 2018); and, Jubin M. Goodarzi, Syria and Iran: Diplomatic Alliance and Power Politics in the Middle East (London: Tauris Academic Studies, 2006), 59.
} 


\section{Khurram Abbas}

structures in order to address challenges to social and political sustainability. ${ }^{79}$ This reassessment comes only a few years after the Arab Spring uprisings, in reaction to which these states spent extensively in implementing emergency economic and security measures to counter the movement's impact and to ensure order in the region. Therefore, these countries are diversifying their economies as well as expanding diplomatic relations with Asian countries in general, and India in particular, in order to seek international support for their regimes, reduce their overwhelming reliance on the US-led Western countries in terms of economic, political support and arms sales. India has voted thrice against Iran's nuclear programme in the UN, which is explicit support to the Arab ruling elite against their perceived threat from Iran ${ }^{80}$ Furthermore, such insecurity is also compelling them to seek support of Muslim countries with a popular notion 'either you are with us or against us'.

In this regard, Pakistan has adopted a neutral position in intra-Arab conflicts. Its neutrality on Yemen, ${ }^{81}$ Qatar's diplomatic crisis, and its support of Iran's nuclear deal has annoyed the Arab ruling elite. This has further pushed the GCC states towards India. Former President Pervez Musharraf believes that Pakistan should have supported Saudi Arabia and the UAE in the Qatar diplomatic crisis. ${ }^{82}$ Contrary to this, strategists believe that neutrality is in the country's national interest as this may give Islamabad leverage over the GCC. Pakistan also hopes that through this policy it can act as a mediator between Iran and Saudi Arabia. ${ }^{83}$ However, this may have a damaging impact on the country's short-term relationship

\footnotetext{
${ }^{79}$ Kristian Coates Ulrichsen, "Internal and External Security in the Arab Gulf States," Journal of Middle East Policy XVI, no. 2 (2009), https://doi.org/10.1111/j.14754967.2009.00390.x.

${ }^{80}$ Stuti Bhatnagar, “The US Shadow over India's Iran Policy,” Interpreter, July 23 2018,https://www.lowyinstitute.org/the-interpreter/us-shadow-over-indias-iran-policy.

81 "Parliament Calls for Neutrality in Yemen Conflict," Dawn, April 10, 2015, https://www.dawn.com/news/1175090.

82 "Musharraf Urges Pakistan to back UAE, Saudi Arabia against Qatar," Dawn, December 12, 2017, https://www.dawn.com/news/1376073.

${ }^{83}$ Air Cdr. (R) Khalid Iqbal, (Senior Defence Analyst and Chairman, Institute of Policy Studies Committee on Pakistan's Geostrategic and Geopolitical Dynamics) in discussion with the author, September 8, 2018.
} 
India's Growing Influence in the Gulf States: Political, Strategic and Economic Risks for Pakistan

with the member states. ${ }^{84}$ This, coupled with India's strategic and economic presence in the region, has restricted Saudi Arabia, UAE and other Gulf states to only customary statements on the Kashmir dispute under the platform of the Contact Group of OIC. ${ }^{85}$ This is a serious setback to Pakistan's Kashmir cause as the country needs extensive diplomatic support in general, and from Muslim countries, in particular. In contrast to Iran and Turkey, the GCC states have maintained silence on the recent uprising of Kashmiri people against Indian atrocities. Killing of Burhan Wani and excessive use of pellet guns by the Indian security forces have been officially ignored by the GCC states since 2016. During the visit of Crown Prince Muhammad bin Zayed, the Kashmir dispute was not mentioned in the official press release given UAE's economic relationship with India. ${ }^{86}$ Furthermore, the OIC not only invited India to the $46^{\text {th }}$ Ministerial session, but has also de-hyphenated Kashmir from Palestine, evident from its final communiqué ${ }^{87}$ It is important to mention that India has been pursuing a policy of isolating Pakistan at international arenas. ${ }^{88}$ On May 24, 2017, Lt. Gen. Vincent Stewart, Director, Defense Intelligence Agency, USA also highlighted New Delhi's intentions against Pakistan in front of the Senate Armed Services Committee during a Congressional hearing on worldwide threats. ${ }^{89}$ India can directly enforce this policy on South Asian countries as it compelled member countries of

${ }^{84}$ Ambassador (R) Javed Hafeez (former Ambassador of Pakistan to Saudi Arabia), in discussion with the author, September 5, 2018.

${ }^{85}$ This group is comprised of Foreign Ministers from Pakistan, Turkey, Saudi Arabia, Azerbaijan, Niger and OIC's Secretary General.

${ }^{86}$ Ministry of Foreign Affairs of Pakistan, "Visit of Crown Prince of UAE," (press release January 6, 2019), http://www.mofa.gov.pk/pr-details.php.

${ }^{87}$ Organization of Islamic Cooperation, "OIC holds 46th CFM Session in Abu Dhabi: 50 Years of Islamic Cooperation: Roadmap for Prosperity and Development," (February 26, 2019), https://www.oic-oci.org/topic/?t_id=20621\&t_ref=11715\&lan=en; and, Muhammad Saleh Zaafir and Sibte Arif, "OIC keeps Kashmir out of Final Dispatch," News, March 3, 2019, https://www.thenews.com.pk/print/439233-oic-keeps-kashmirout-of-final-dispatch

88 "Modi says India will Work to 'Isolate' Pakistan Internationally," Dawn, September 24, 2016, https://www.dawn.com/news/1285839.

89 "India working towards Internationally Isolating Pakistan, Claims US Defence Expert," Firstpost, May 24, 2017, https://www.firstpost.com/india/india-working-towardsinternationally-isolating-pakistan-claims-us-defence-expert-3474958.html. 


\section{Khurram Abbas}

the South Asian Association for Regional Cooperation (SAARC) to not attend the Summit in Islamabad. ${ }^{90}$ However, the same approach cannot work in other regions. Resultantly, India has exercised an indirect approach through increased interdependence, extensive economic engagement, political and security cooperation. This is evident from Saudi Arabia's unexpected decision of abstain in a crucial meeting of the Financial Action Task Force (FATF). Resultantly, Pakistan was put in the grey list. ${ }^{91}$ Kuwait - a non-permanent member of the United Nations Security Council (UNSC) - has recently supported India's stance on the Pulwama attack at the Council. ${ }^{92}$ If such tactics expand to other Gulf countries, Pakistan is likely to be in a difficult position. However, another school of thought in Islamabad remains optimistic:

Though, it is India's longstanding wish to strip Pakistan off GCC support, we have done so many favours to these countries and that too when they badly needed them. Their militaries were raised and trained by Pakistan. Their airlines were made functional by our PIA. Their infrastructure was developed by Pakistani manpower. Pakistan fought their wars, and has always extended overwhelming support to the Palestinian cause and lastly, by nature Arabs are not forgetful. ${ }^{93}$

90 "SAARC: Maldives Joins India, 4 Others in Boycott; Pak's Isolation Complete," India Today, October 1, 2016, https://www.indiatoday.in/world/story/saarc-summit-maldivesjoins-india-pakistan-isolation-complete-344244-2016-10-01.

91 Anwar Iqbal, "Pakistan Placed on FATF 'Grey List' Despite Diplomatic Efforts to Avert Decision," Dawn, June 28, 2018, https://www.dawn.com/news/1416630.

92 Dipanjan Roy Chaudhury, "China Tried to Water down UNSC's Statement on Pulwama Terror Attack," Economic Times, February 23, 2019,

//economictimes.indiatimes.com/articleshow/68121663.cms?utm_source=contentofinter est\&utm_medium=text\&utm_campaign=cppst.

${ }^{93}$ Air Cdr. (R) Khalid Iqbal, (Senior Defence Analyst and Chairman, Institute of Policy Studies Committee on Pakistan's Geostrategic and Geopolitical Dynamics) in discussion with the author, September 8, 2018. 


\section{India's Growing Influence in the Gulf States: Political, Strategic and Economic Risks for Pakistan}

Moreover, it seems that Saudi Arabia still has hopes attached with Pakistan which is evident from recent engagement between the two countries. The Jeddah-based Islamic Development Bank (IDB) announced financial offering of USD 4 billion as a goodwill gesture. ${ }^{94}$ Subsequently, Prime Minister Imran Khan visited Saudi Arabia and UAE twice within one month. Resultantly, both pledged economic support of USD 6 billion and USD3 billion, respectively to support the country's fragile economy. There are mainly two reasons for this recent policy shift. The fear of international isolation is one. Despite the fact that Saudi Arabia is the second largest arms buyer from Germany after Algeria, Berlin has halted arms deals worth USD 4.65 million. ${ }^{95}$ France has also stopped diplomatic visits. ${ }^{96}$ The G7 countries have demanded a credible investigation of Jamal Khashoggi's death and many Western firms boycotted an International Investment conference, which was held in Riyadh in October 2018. Initially, the Trump administration considered Saudi explanations credible. However, it also changed its stance on this issue due to severe pressure from civil society, media and Congress. The UN General Secretary also demanded fair trial of the culprits. ${ }^{97}$ These actions have isolated Saudi Arabia diplomatically from its tested allies. This also means that the West may no longer support the Saudi-led coalition operation against Yemen's Houthi rebels. Therefore, the Kingdom held a truce with the rebels at Hodeidah sea port. ${ }^{98}$ It has also hinted financial support for

94 "Saudi-backed IDB Ready to Help Imran-led Government with \$4 billion Loan,” Dawn, August 10, 2018, https://www.dawn.com/news/1426093.

95 "Germany Ends All Arms Sales to Saudi Arabia," Haaretz, November 19, 2018, https://www.haaretz.com/middle-east-news/germany-ends-all-arms-sales-to-saudiarabia-1.6661727; and, "Germany Extends Ban on Arms Exports to Saudi Arabia," Deutsche Welle, March 6, 2019, https://www.dw.com/en/germany-extends-ban-onarms-exports-to-saudi-arabia/a-47795840.

${ }^{96}$ Helene Fouquet, "Macron Suspends French Political Visits to Saudi Arabia," Bloomberg, October 18, 2018, https://www.bloomberg.com/news/articles/2018-1018/macron-suspends-french-political-visits-to-saudi-arabia.

97 UN Chief 'Deeply Troubled' by Saudi Confirmation of Jamal Khashoggi's Death," United Nations News, October 19, 2018, https://news.un.org/en/story/2018/10/1023722.

98 Aziz El Yaakoubi and Michelle Nichols, "Yemen's Parties Agree to Start Stalled Troop Withdrawal from Main Port," Reuters, February 18, 2019,

https://www.reuters.com/article/us-yemen-security-un/yemens-parties-agree-to-startstalled-troop-withdrawal-from-main-port-idUSKCN1Q60QY. 


\section{Khurram Abbas}

reconstruction of Syria as well as resumption of Syrian membership in the Arab League (AL) ${ }^{99}$ which was suspended in November 2011. Second, Turkey has been rigorously pursuing Khashoggi's case since October 2018, and its strategy of slowly but consistently revealing facts related to the Saudi journalist's murder has embarrassed the Kingdom worldwide. On December 24, Turkey announced taking the case to the UN. These international developments offer both, a golden opportunity for Pakistan to reinvigorate its significance in the GCC; and a challenge to maintain neutrality. It is likely that the Saudi kingdom has realised that Pakistan can be a better ally with little payoffs as compared to spending billions of dollars on Western allies, especially the US.

Successive governments have stated that Pakistan would protect Saudi Arabia's territorial integrity. ${ }^{100}$ However, contrary to assurances, Islamabad decided to stay neutral in Saudi-led intervention against Yemen's Houthis in 2015. ${ }^{101}$ This is considered to be an unprecedented and historic decision with strategic ramifications. The UAE Deputy Foreign Minister Dr Anwar Mohammed Gargash warned Pakistan in this regard. ${ }^{102} \mathrm{~A}$ few months later, Narendra Modi was conferred the highest civil award in Saudi Arabia, ${ }^{103}$ considered as reaction to Pakistan's policy of neutrality in the region. During Modi's state visit to the Kingdom, both countries signed a joint statement and condemned cross-border terrorism

${ }^{99}$ Bethan McKernan and Martin Chulov I, "Arab League Set to Readmit Syria Eight Years after Expulsion," Guardian, December 26, 2018,

https://www.theguardian.com/world/2018/dec/26/arab-league-set-to-readmit-syriaeight-years-after-expulsion.

100 "Nawaz Assures Saudi King Salman of Pakistan Army Support," Dawn, March 28, 2015, https://www.dawn.com/news/1172460; "Saudi King meets Gen. Raheel, Vows to Help Eliminate Terrorism," Dawn, November 4, 2015, https://www.dawn.com/news/1217466; and "General Qamar Bajwa Calls on Saudi King Salman, Vows to Guard Holy Mosques," Dawn, December 18, 2016, https://www.dawn.com/news/1303100.

101 "Parliament Calls for Neutrality in Yemen Conflict," Dawn, April 10, 2015, https://www.dawn.com/news/1175090.

102 "UAE Minister Warns Pakistan of 'Heavy Price for Ambiguous Stand' on Yemen," Dawn, April 11, 2015, https://www.dawn.com/news/1175284.

103 "PM Modi Conferred Saudi's Highest Civilian Honour,"' India Express, April 3, 2016, https://indianexpress.com/article/india/india-news-india/modi-saudi-arabia-kingabdulaziz-sash-civilian-honour/. 
India's Growing Influence in the Gulf States: Political, Strategic and Economic Risks for Pakistan

and to cut support of such states that provide safe havens to terrorists. Typically, New Delhi assigns 'cross-border terrorism' to Pakistan. Therefore, such a statement may be indicative of change in the Saudi Arabia's strategic thinking. Moreover, the latter also voted in favour of proscription of a number of militant groups, including Lashkar-e-Taiba (LET) two days before Modi's visit, which is unprecedented. ${ }^{104}$

Although, Pakistan initiated diplomatic damage control through frequent high-ranking official visits and support of the Saudi-led Islamic Military Counter Terrorism Coalition (IMCTC), yet, it can be observed that there is likely to be a trust deficit among the Arab ruling elite about Pakistan's practical support to Saudi forces in the future. While India has also adopted a policy of neutrality in intra-Arab conflicts, it has never promised unconditional support during any crisis. Moreover, the GCC states realise the latter's significance as an emerging political and economic power in Asia and beyond. Similarly, it is aspirant for important positions in various international foras, like the UNSC which is likely to be seen positively by these states. Therefore, the GCC states react differently to the same neutral position of India and Pakistan.

The Gulf region in general and Saudi Arabia in particular consider the US as their guardian against any possible threat from Iran. ${ }^{105}$ Pakistan has been training the Saudi military, and is considered to be the second security guarantor to the Kingdom. ${ }^{106}$ While it is too early to consider India as Pakistan's replacement, speedy evolution and closer cooperation between India and Gulf states is foreseeable given New Delhi's stance on Iran's nuclear programme, which will squeeze Pakistan's options of neutrality in the region. This is evident from KSA's decision to train its cadets at the National Defence Academy of India. ${ }^{107}$

104 Naveed Ahmad, “India after Modi's Saudi Offensive," Express Tribune, April 12, 2016, https://tribune.com.pk/story/1083500/india-after-modis-saudi-offensive/.

105 Prasanta Kumar Pradhan, "GCC-Iran Rivalry and Strategic Challenges for India in the Gulf," Indian Foreign Affairs Journal 6, no. 1 (March 2011): 45-57 (51).

106 Kamal Alam, "Pakistan's Middle East Policy: Turkey, Syria and Beyond," (speech, International Conference Pakistan's Geo-Strategic Requirements: Strategic Alliances or Partnerships, Islamabad, September 5, 2018).

107 Rashid Hassan, "Saudi Cadets to Undergo Training in India," Arab News, March 19, 2018, http://www.arabnews.com/node/1328011/saudi-arabia. 
Khurram Abbas

Historically, Saudi Arabia supported Pakistan financially and diplomatically during the 1965 War. ${ }^{108}$ King Faisal termed Indian aggression in East Pakistan during 1971 as 'treacherous and contrary to all international covenants and human values'. He also maintained that 'there is no justification for the Indian aggression except India's desire to dismember Pakistan and tarnish its Islamic creed. ${ }^{109}$ It was also King Faisal's unflinching support that he loaned 75 warplanes to Pakistan. ${ }^{110}$ However, a shift is evident in Riyadh's policy towards South Asian conflicts. During the recent Pakistan-India border escalation, Riyadh tried to mediate between the two nuclear neighbours instead of siding with Islamabad due to its deepening political, economic and cultural interests with New Delhi. This development will have long-term impact on Pakistan's political interests as India has been able to transform Riyadh's support into neutrality or mediation. Hence, Pakistan is facing multidimensional political risks due to India's ingress in the region.

\section{Strategic Risks}

A significant development under India's 'Look West' policy has been its bilateral cooperation with Oman. Under an agreement, India has been given access to the strategic and economically important Duqm Port. ${ }^{111}$ While this is meant to combat piracy, maintain and refuel Indian ships, it can pose a strategic risk to Pakistan due to its juxtaposition to the Gwadar Port. ${ }^{112}$ Although, Pakistan and Oman share a historic and cordial relationship, yet overall reliance of the latter on India has been

\footnotetext{
108 “Asia: Silent Guns Wary Combatants," Times, October 1, 1985, http//content.time.com/time/magazine/article/0,9171,834413,00.html.

109 Sabha E. Nagib, "Impact of Indo-Pakistani Wars on the Middle East," World Affairs 135, no.2 (1972): 131.

110 S.M. Burke, Pakistan's Foreign Policy: An Historical Analysis (London: Oxford University Press, 1973), 214.

111 Shubhajit Roy, "India Gets Access to Strategic Oman Port Duqm for Military Use, Chabahar-Gwadar in Sight," Indian Express, February 13, 2018, https://indianexpress.com/article/india/india-gets-access-to-strategic-oman-port-formilitary-use-chabahar-gwadar-in-sight-5061573/.

112 Dr Azhar Ahmad (former Naval Officer and Head of Department, International Relations, Bahria University), in discussion with the author, September 5, 2018.
} 
substantially increasing over the years. The two have signed several defence agreements such as MoU on Crime and Combating Terrorism 1996; Defence Cooperation MoU 2005; and formed a Military Cooperation Committee in 2006. According to defence analysts, such agreements are part of New Delhi's greater strategy to keep an eye on and act as a balancer to China. ${ }^{113}$ Gwadar Port, under the China-Pakistan Economic Corridor (CPEC) offers an alternative route to China, to secure its Middle East oil supplies. However, India has been concerned that the Port will serve as a military base,${ }^{114}$ in spite of China refuting such claims. ${ }^{115}$ India's narrative is likely an effort to justify its naval presence near Gwadar since Duqm has potential to be converted into a military base. ${ }^{116}$ India's naval presence near Gwadar will create deterrence for Chinese and Pakistani navies. ${ }^{117}$ There is a concern of 'Chinese marginalization by the US and West' within the academic community of China. ${ }^{118}$ Growing India-GCC relations are also seen from this security lens. ${ }^{119}$ This is why Beijing has started robust cooperation with the GCC

113 Grare, India Turns East, 11.

114 Imtiaz Ahmad, "China Plans to Build Offshore Naval Base in Pakistan's Gwadar Port," Hindustan Times, January 9, 2018, https://www.hindustantimes.com/worldnews/china-plans-to-build-offshore-naval-base-in-pakistan-s-gwadar-port-saysreport/story-zcC2K12j5negjrekKUyPdI.html; and, Rajeswari Pillai Rajagopalan, "A New China Military Base in Pakistan,” Diplomat, February 9, 2018, https://thediplomat.com/2018/02/a-new-china-military-base-in-pakistan/.

115 "China Rejects Speculations of Military Base in Gwadar," Express Tribune, January 10, 2018, https://tribune.com.pk/story/1604988/1-china-rejects-speculations-militarybase-gwadar/; and, "Pakistan Denies Report of Chinese Military Base near Gwadar," Economic Times, January 4, 2018,

https://economictimes.indiatimes.com/news/defence/pakistan-denies-reports-ofchinese-military-base-near-gwadar/articleshow/62370796.cms.

116 Cdr. (R) Baber Bilal (Director, Institute of Maritime Affairs), in discussion with the author, September 5, 2018. There is hardly 415 nautical miles between the two ports. The strategic location of Duqm makes Gwadar vulnerable if tensions arise between India and Pakistan or China and India.

117 Cdr. (R) Baber Bilal (Director, Institute of Maritime Affairs), in discussion with the author, September 5, 2018.

118 Xuming Qian and Jonathan Fulton, "China-Gulf Economic Relationship under the Belt and Road' Initiative," Asian Journal of Middle Eastern and Islamic Studies 11, no.3 (2017): 12-21, doi: 10.1080/25765949.2017.12023306 .

11 Dr Hu Reifeng (Senior Research Fellow, Yunnan Academy of Social Sciences, China), in discussion with the author, December 27, 2018. 
in general, and Saudi Arabia in particular, in order to neutralise the impact of an evolving Indo-GCC nexus.

Under the Belt and Road Initiative (BRI), China is expecting a significant boost in trade cooperation with the GCC states. Energy, trade and infrastructure development are key areas in this regard. According to a report by the International Energy Agency (IEA), 70 per cent of the country's energy requirements are met by the GCC states. It is expected that Beijing will gradually redirect its oil supplies via Gwadar once it becomes operational. Any attempt to hinder the Gwadar route can give rise to serious security complications by accentuating the nuclear arms race and militarisation of the Indian Ocean. Under a worst case scenario, India has the capacity to choke the Strait of Hormuz for Chinese and Pakistani vessels. ${ }^{120}$ India's ingress in this region is directly linked to China's active cooperation with Pakistan and operationalisation of Gwadar. Hence, extensive Pak-China diplomatic and strategic oversight is required to ensure that Duqm is not converted into a military base. In this context, continuous bilateral diplomatic engagement for improved connectivity between Duqm and Gwadar ports has been initiated by Islamabad. ${ }^{121}$ However, it is unclear whether Oman will positively respond to this offer or not, but, this has created a favourable environment to start a symbolic strategic dialogue between the two countries. It should be pointed out that Indians also make up Oman's largest expatriate community.

\section{Economic Risks}

One Chinese expert believes that the economic sector of Pakistan is the biggest 'victim' of India's growing cooperation with the Gulf region. Economic risks for Pakistan given Indo-GCC cooperation include impact on Foreign Direct Investment (FDI), remittances and exports. FDI from

120 Lee Hudson Teslik, "China-Gulf Economic Relations," (Council on Foreign Relations, June 2, 2008), https://www.cfr.org/backgrounder/china-gulf-economic-relations; and Gal Luft, "Fuelling the Dragon: China's Race into the Oil Market," (Institute for the Analysis of Global Security, 2003-04), http://www.iags.org/china.htm.

121 Ministry of Foreign Affairs Pakistan, "Foreign Minister Shah Mahmood Qureshi met Foreign Minister of Oman H.E. Yusuf Alawi,” press release, January 30, 2019, http://www.mofa.gov.pk/pr-details.php. 
India's Growing Influence in the Gulf States: Political, Strategic and Economic Risks for Pakistan

the Gulf region is shrinking, while that of India is relatively increasing. In FY 1998-99, Saudi Arabia and UAE invested USD 43.8 million in agriculture and petroleum sectors of Pakistan; in FY 2000-01, both countries invested nearly USD 50 million. From 1997-2001, FDI was nearly USD 200 million when the country was facing severe economic sanctions due to its nuclear tests. ${ }^{122}$ This investment was not only a great economic help, but also a political support to the country. However, data from 2013-16 was very discouraging for Pakistan (see Table 3).

Table-3

Foreign Direct Investment of GCC States (USD Million)

\begin{tabular}{|c|c|c|c|c|c|c|}
\hline Year & Bahrain & Kuwait & Qatar & KSA & Oman & UAE \\
\hline 2013 & 1.7 & 10.7 & -22 & 3.3 & 2.5 & 47.1 \\
\hline 2014 & -1.9 & 1.7 & 59.5 & 68.9 & 36.2 & 213 \\
\hline 2015 & 4.3 & 2.3 & -34.5 & -64.5 & -11.5 & 109 \\
\hline 2016 & 5.3 & 16.5 & -15.4 & 24.9 & 1.2 & 120 \\
\hline Source: & $\begin{array}{l}\text { State Bank } \\
\text { Country W } \\
\text { http://wwW }\end{array}$ & $\begin{array}{l}\text { Pakistan, } \\
\text { "March } \\
\text {.org.pk/ }\end{array}$ & $\begin{array}{l}\text { Inflov } \\
019 \text {, }\end{array}$ & & & \\
\hline
\end{tabular}

The table depicts a sharp decline of FDI from GCC states to Pakistan. There are various reasons of this sharp decrease in FDI such as low economic growth of the Gulf region due to decrease in oil prices and excessive military spending due to intra-Arab conflicts. On the Pakistani side, the fragile security situation, severe energy crisis and a weak Ease of Doing Business index have also contributed in lower investments. Another important factor is changing priorities of Arab investors who

122 State Bank of Pakistan, "Net Inflow of Foreign Private Investment- Country-wise (Old Format)," June 4, 2012, http://www.sbp.org.pk/ecodata/NIFP_Arch/index.asp. 


\section{Khurram Abbas}

largely prefer India over Pakistan in agriculture, IT, telecommunication and petroleum sectors. ${ }^{123}$ This is evident from the FDI of Gulf region to India in the same time period. From 2001 to 2016, the FDI from UAE to India increased manifolds. The UAE invested more than USD 5 billion in India in 2017 which makes it the third largest investment partner after China and the US. ${ }^{124}$ While India's economy is much larger than that of Pakistan, increase in FDI in India and its decline for Pakistan portrays a priority shift of Arab investors, which was not the case earlier.

Pakistan's economy heavily relies on the remittances of expatriate Pakistanis working in Gulf states. According to the Ministry of Foreign Affairs, there are 3.76 million Pakistani citizens working in Gulf countries. ${ }^{125}$ This figure has been stagnant for the last few years, ${ }^{126}$ while India's expatriate community has been increasing due to higher allocation of visas to Indians by Arab employers due to their work ethics as well as the comprehensive bilateral agreements in various fields. ${ }^{127}$ In 2018 , Saudi Arabia introduced new taxes on expatriates in order to expand revenues and encourage companies to hire Saudi citizens. This policy has pushed and continues to push expatriates out of the Kingdom. majority of Pakistani expatriates prefer independent work visas, while most Indians prefer to work in a Saudi company. ${ }^{128}$ Consequently, the tax hike has severely hit Pakistani workers. Furthermore, Pakistani expatriates are mostly unskilled workers, while Indian workers are semi-skilled or skilled earning more money. ${ }^{129}$

123 Ibid.

${ }^{124}$ Issac John, “UAE-India Trade likely to Cross \$100 Billion by 2020,” Khaleej Times, April 17, 2018, https://www.khaleejtimes.com/business/economy/uae-india-tradelikely-to-cross-100-billion-by-2020.

125 "Statistics of Overseas Pakistanis Abroad: Country Wise," Ministry of Foreign Affairs Handbook, 25, accessed September 4, 2018, http://www.mofa.gov.pk/documents/handbook.pdf.

${ }^{126}$ Asim Ahmed and Mahroona Hussain Syed, "Strategic Expediency or Sway: Analysing Pakistan's Case for Joining the Islamic Military Alliance," IPRI Journal XVII, no. 2 (2017): 69-95, http://www.ipripak.org/wp-content/uploads/2017/09/art4ijs2017.pdf.

127 Ibid.; Ahmad, "India After Modi’s Saudi Offensive."

128 Ibid.

129 Ibid. 
India's Growing Influence in the Gulf States: Political, Strategic and Economic Risks for Pakistan

According to the Trade Development Authority of Pakistan (TDAP), remittance inflow from Saudi Arabia, UAE and other GCC states decreased by $5.84,3.26$ and 1.58 per cent, respectively during FY 2017-18 as compared to FY 2016-17. ${ }^{130}$ Moreover, the exports sector also shrank in the Gulf region over the past few years. According to Pakistan's Ministry of Commerce, the country's exports to Saudi Arabia, Oman, UAE, and Bahrain decreased by 20.61, 17.31, 14.19, and 11.13 per cent, respectively in FY 2016-17. ${ }^{131}$ This space by and large has been filled by India as depicted in the annual report 2017-18 issued by its Ministry of Commerce and Industry. ${ }^{132}$ According to this report, Indian export sector has gained 2.6 per cent in the Gulf region during FY 2017-18. ${ }^{133}$ Therefore, it is safe to claim that Pakistan's economy is facing three pronged risks due to India's economic might in the Gulf region.

\section{Recommendations}

Pakistan should take several steps to strengthen its relationship with the GCC member states. This includes institutionalising cooperation by entering into formal agreements and MoUs. Other areas include:

\section{Political}

- Pakistan signed various defence pacts with the GCC states during the Cold War and post-Cold War era. However, the geopolitical and geostrategic situation in the Middle East and South Asia has

${ }^{130}$ Afshan Uroos, "Pakistan's Trade Statistics: Month Review," Trade and Development Authority of Pakistan (TDAP), December 1, 2017, https://www.tdap.gov.pk/word/JulyOctober\%202017-18.pptx.

${ }^{131}$ Ministry of Commerce, "List of Countries where Pakistan's Exports showed a Decline of More than 5\% (July-Dec 2015-16 to July-Dec 2016-17)," accessed September 9 , 2018, https://www.commerce.gov.pk/wpcontent/uploads/pdf/Countries_Where_Decline_Exports_Pakistan.pdf.

${ }^{132}$ Ministry of Commerce and Industry, Annual Report 2017-18, Government of India, , accessed September 9, 2018, http://commerce.gov.in/writereaddata/uploadedfile/MOC_636626711232248483_Ann ual\%20Report\%20\%202017-18\%20English.pdf. .

${ }^{133}$ Ibid., 91. 
fast changed after 9/11. There is a need to revisit those pacts and protocols to update them in the light of ongoing developments in the two regions. The signing of protocols and agreements on joint defence production, anti-money laundering, drug trafficking and curbing terror financing, cooperation in deradicalisation of extremist elements etc. would be beneficial.

- Pakistan requires a foreign policy shift to address the concerns of the Saudi royal family. In this regard, Islamabad should enhance its security assistance to Riyadh by providing training to Saudi Law Enforcement Agencies (LEAs) and security forces for their capacity building and improved border management.

- Pakistan needs to work with Kuwait and Oman for mediation between Saudi Arabia and Qatar to end intra-GCC diplomatic tensions. Such a role may enhance the country's political stature in the GCC states.

\section{Security}

- Due to geopolitical shifts in the Middle East and South Asia, Pakistan and the GCC states are investing heavily in their defence sector. Pakistan is striving to achieve indigenisation and improve sales of small and heavy artilleries. The latter can be done by seeking GCC' investment in its armament programmes and joint research and development $(\mathrm{R} \& \mathrm{D})$ in military hardware.

- Islamabad needs to consistently share its security concerns with Muscat on its decision about Duqm Port. Moreover, it should enhance its diplomatic engagement with Oman through multilateral initiatives such as military-to-military cooperation, military trainings, economic and cultural agreements in the fields of education, agriculture and business. Establishment of a Joint Strategic Council between the two countries can further streamline interests and help address mutual concerns.

- Relations between Oman and Qatar are growing amid the latter's blockade by Saudi Arabia. Pakistan can ask for Qatari support to 
India's Growing Influence in the Gulf States: Political, Strategic and Economic Risks for Pakistan

convince Oman to either undo its strategic decision about India's access to Duqm Port or guarantee its peaceful use.

- Pakistan has rich experience in dealing with hybrid threats like terrorism, insurgency and cybercrimes. Pakistan and the GCC states could formalise exchange of knowledge on counterterrorism (CT), counterinsurgency, anti-money laundering and terrorism financing. However, this requires effective marketing and projection via diplomatic efforts and bilateral state visits.

\section{Economic}

- Pakistan and the GCC states should work on granting each other Most Favoured Nation (MFN) status. Both China and India have granted MFN status to the Gulf countries and are reaping the benefits of free trade and investments.

- Pakistan should invite other GCC states to invest in the ChinaPakistan Economic Corridor (CPEC). This will help the government in not only meeting the shortfall in investment, but will also deflect international pressure on the project.

- It is vital to sign agreements or protocols to ensure protection of Pak-GCC citizens in each other's territory. Such an agreement already exists between the GCC states and India.

\section{Education and Culture}

- In recent years, the GCC states have become a hub of educational institutions attracting thousands of foreign students. Medina Knowledge City in Saudi Arabia, Dubai Knowledge Park in UAE and Education City in Qatar are just a few instances of this knowledge revolution in that region. Pakistani universities need to enhance education and research collaboration with the GCC through students and scholar exchange programmes, and joint research ventures.

- Pakistan should encourage media-to-media ties with the GCC states, especially in the field of entertainment. In this regard, 
Khurram Abbas

Pakistani television serials should be dubbed in Arabic and marketed.

\section{Conclusion}

Under its 'Look West' policy, India has coherently strategised its priorities towards the Middle East and adopted a rational approach to achieve its objectives. Frequent state-level bilateral visits and extensive economic cooperation has synchronised Indo-Arab thinking in the areas of energy security, trade and investment, and cross-border terrorism. By doing so, successive administrations, and now especially Prime Minister Modi, have substantially developed New Delhi's economic clout. Balancing China, strengthening its alignment with the US, presence of a strong expatriate community and promoting its soft image are the key motivating drivers behind India's growing cooperation with the GCC states, in particular. These developments indicate that the country's political presence will become inevitable for these states in the foreseeable future. Security cooperation, though still in its nascent stage, is also likely to develop.

Pakistan, on the other hand, has strong religious, historical, political, trade and security links with the Gulf region. Except a few economic setbacks, currently, India's political and strategic ingress does not pose serious threat to Pak-GCC ties. However, this could change in the long-term impact. Lack of support for the Kashmir cause; diminishing political support of Gulf states at international forums; security of Gwadar Port; lesser use of human resources or expelling workers from the Gulf; less FDI in agriculture and petroleum sectors are some areas where Pakistan is facing problems due to India's growing relationship with the GCC. Furthermore, Pakistan's recent foreign policy decisions such as supporting Iran's nuclear deal; neutrality in the Qatar diplomatic crisis; and declining Saudi Arabia's request for troops in Yemen's war have provided impetus to India-GCC countries cooperation and compelled the Arab leadership to think beyond Pakistan for their security. Hence, Pakistan needs to work on aforementioned recommendations to revive its 
India's Growing Influence in the Gulf States: Political, Strategic and Economic Risks for Pakistan

relationship with the GCC states in order to neutralise implications generating from India's growing influence and presence in the region. 